\title{
Respiratory effects of chlorine gas
}

\author{
F. X. M. BEACH, E. SHERWOOD JONES, AND G. D. SCARROW \\ The Intensive Care Unit, Whiston Hospital, Prescot, Lancashire, and the Department of \\ Radiodiagnosis, University of Liverpool
}

\begin{abstract}
Beach, F. X. M., Sherwood Jones, E., and Scarrow, G. D. (1969). Brit. J. industr. Med., 26, 231-236. Respiratory effects of chlorine gas. Seven chemical workers who were accidentally exposed to chlorine gas in separate accidents were investigated. The usual symptoms were cough, dyspnoea, and chest pains, the symptoms starting within 10 minutes of exposure and lasting two to eight days. Chest radiographs showed congestion, consolidation, and nodules; lung oedema was also present in a severe case. These changes usually cleared within one week but in the severe case persisted for 10 weeks. Three patients had respiratory failure. Hypoxaemia was found in four patients and was quickly corrected by oxygen therapy in three of them, but in the severe case hypoxaemia persisted for four days despite continuous oxygen therapy. All the patients recovered completely.
\end{abstract}

Half a million tons of chlorine are produced in this country every year; the bulk of this is manufactured locally. Despite this, serious accidents during manufacture or transportation are rare. Jones (1952) reported 820 cases of chlorine gassing from the local factories, but only seven cases were clinically severe and none of his patients died. In 1967 a man aged 49 died from lung oedema three hours after gassing, and this, as far as we know, is the only fatality in this region (Whitehead, personal communication). During the past year we have studied the natural history, chest radiograph, and arterial blood of process workers exposed to chlorine in our local factories.

\section{Clinical findings}

Table 1 shows the clinical findings on our seven patients, one of whom had chronic bronchitis (M.R.C. definition, 1965). Six men had mild or moderate illnesses which lasted two to eight days. The usual symptoms were conjunctivitis, cough, breathlessness, and chest pains. With one exception (patient no. 6) the onset of the symptoms followed within 10 minutes of exposure. The illness threatened the life of our first patient, and the natural history can best be described by referring to this case.

\section{Case history}

A 44-year-old process worker was exposed to a high concentration of gas when closing a valve which was allowing liquid chlorine to leak on to the floor. He quickly began to choke and developed severe dyspnoea, a persistent cough, and chest pain. His eyes were smarting. The patient was given oxygen and was transferred to the Intensive Care Unit 10 hours later. He was cyanosed, his breathing was rapid and shallow, and he was coughing up pink, frothy sputum. The conjunctivae were markedly injected and numerous coarse crepitations could be heard. On the second day the patient had a severe headache and pains in the limbs and chest which persisted for two days. He remained critically ill for 48 hours and then gradually improved. The axillary temperature was $100^{\circ} \mathrm{F}$. $\left(37 \cdot 8^{\circ} \mathrm{C}\right.$.) on days 6 and 7, presumably due to respiratory infection; the patient was given tetracycline, $250 \mathrm{mg}$. 6-hourly for five days. The sputum was purulent on day 3 but contained no pathogens.

For nine days the patient was given continuous oxygen. On days 4 and 5 he was cyanosed when allowed to breathe air. The dyspnoea gradually decreased and by the tenth day there was none at rest. He was discharged from hospital after 13 days. Exercise dyspnoea persisted for five weeks. Chest radiographs taken during the illness and on recovery are shown in the Figure. The blood gas findings are given in Table 3. During the illness the blood pressure and electrocardiogram remained normal. No abnormal 
TABLE 1

Clinical Findings

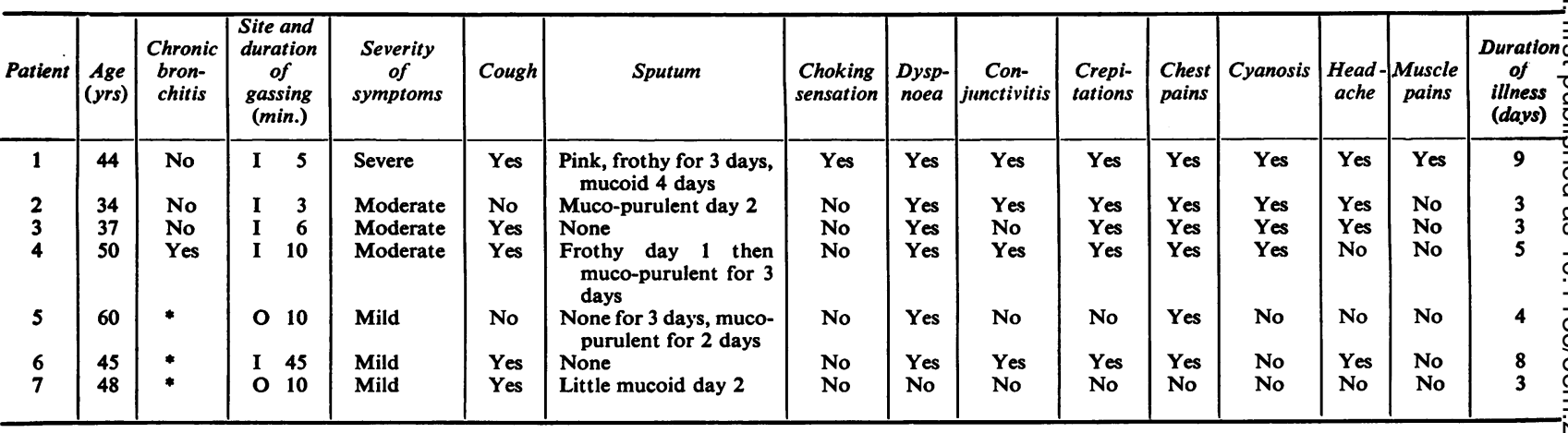

* No data available

$1=$ indoors.

$0=$ outdoors

haemoglobin pigments were found in the blood and the S.G.O.T. was normal.

In addition to continuous oxygen therapy the patient was treated with prednisolone, initially $\mathbf{4 0} \mathrm{mg}$. daily for three days, then $30 \mathrm{mg}$. a day for a further three days. The dose was gradually reduced and stopped after a total of 12 days.

The follow-up was concluded after two months. There were no residual symptoms or signs and the chest radiograph and lung function tests were normal.

\section{Radiographic findings}

Anteroposterior radiographs of the chest were taken on admission and were usually repeated daily. The changes in the radiograph were as follows: congestion, oedema, consolidation, and nodules. Oedema was seen in the severe case only (Figure). Congestion, consolidation or basal nodules were seen in the remaining patients who had mild or moderate illnesses. The radiographic findings are summarized in Table 2. All these acute changes cleared within a week, except in patient no. 1, whose chest film returned to normal after 10 weeks (Figure). Similar radiographic findings have been described previously (Schatzki, 1962).

\section{Laboratory methods}

$p \mathrm{H}$ was determined electrometrically using a capillary electrode (Siggaard Andersen, Engel, Jørgensen, and Astrup, 1960). The electrode was calibrated with two phosphate buffers of $p H \quad 7.416$ and 6.839 at $38^{\circ} \mathrm{C}$. (Semple, Mattock, and Uncles, 1962). The normal range

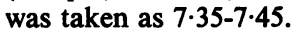

$\mathrm{PaCO}_{2}$ was measured directly with an electrode (Severinghaus and Bradley, 1958), calibrated with two gas mixtures, the $\mathrm{CO}_{2}$ contents of which were determined on the Haldane apparatus (Douglas and Priestley, 1948). Normal values were taken as $33-44 \mathrm{~mm}$. $\mathrm{Hg}$. The $\mathrm{pH}$ and $\mathrm{PaCO}_{2}$ results were used to obtain the base excess or deficit from a nomogram (Siggaard Andersen, 1963).

The $\mathrm{PaO}_{2}$ and $\mathrm{PiO}_{2}$ were estimated by a Clark-type electrode (Radiometer Ltd., type E5046) calibrated with nitrogen, air, and $100 \% \mathrm{O}_{2}$. When gas rather than blood is used to calibrate the oxygen electrode errors increase, the standard deviation increasing from 5-7 $\mathrm{mm}$. $\mathrm{Hg}$ (Flenley, Millar, and Rees, 1967). The alveolar oxygen tension $\left(\mathrm{PAO}_{2}\right)$ and alveolar-arterial gradient $\left(\mathrm{A}-\mathrm{aDO}_{2}\right)$ were calculated from the alveolar gas equations and the equation of Raine and Bishop (1963).

Transfer factor was measured with carbon monoxide

TABLE 2

\section{Chest Radiographs}

\begin{tabular}{|c|c|}
\hline Patient & Findings \\
\hline 1 & $\begin{array}{l}\text { Extensive bilateral pulmonary oedema on admission, clearing after a few days. Consolidation in mid-zones } \\
\text { on day } 3 \text {, slowly resolving. Lung fields clear after } 10 \text { weeks }\end{array}$ \\
\hline $\begin{array}{l}2 \\
3 \\
4 \\
5\end{array}$ & $\begin{array}{l}\text { Congestion, clearing in } 3 \text { days. Basal nodules and patchy consolidation } \\
\text { Congestion only, clearing in } 4 \text { days } \\
\text { Congestion only, clearing in } 6 \text { days } \\
\text { Congestion on admission, clearing after a few days. Basal nodules and pleural thickening } \\
\text { Congestion on admission, clearing in } 5 \text { days } \\
\text { A little congestion, clearing in } 3 \text { days }\end{array}$ \\
\hline
\end{tabular}




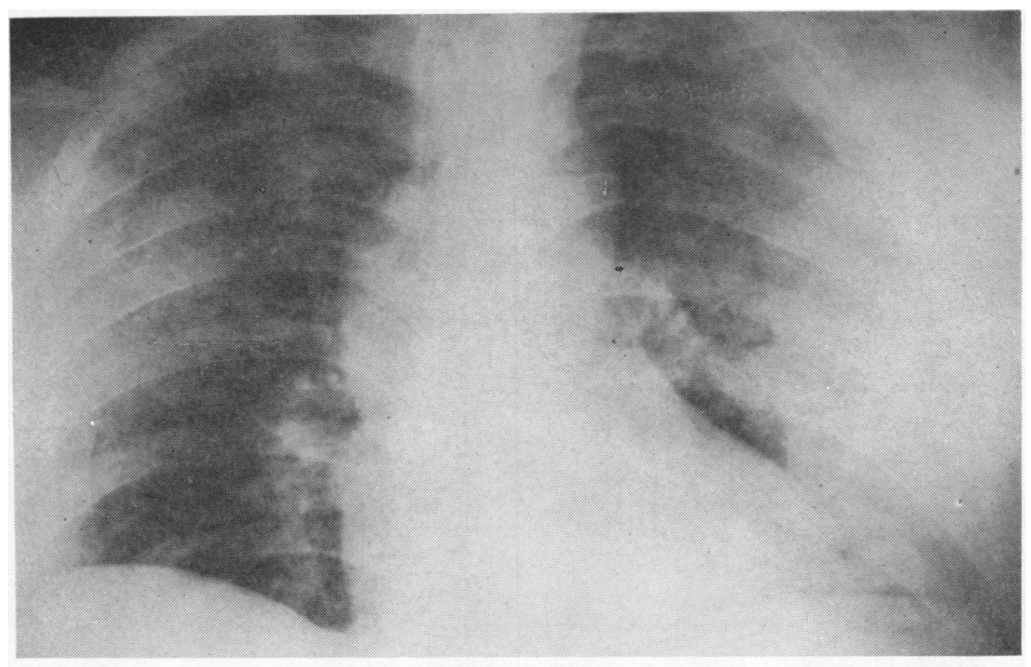

(a)

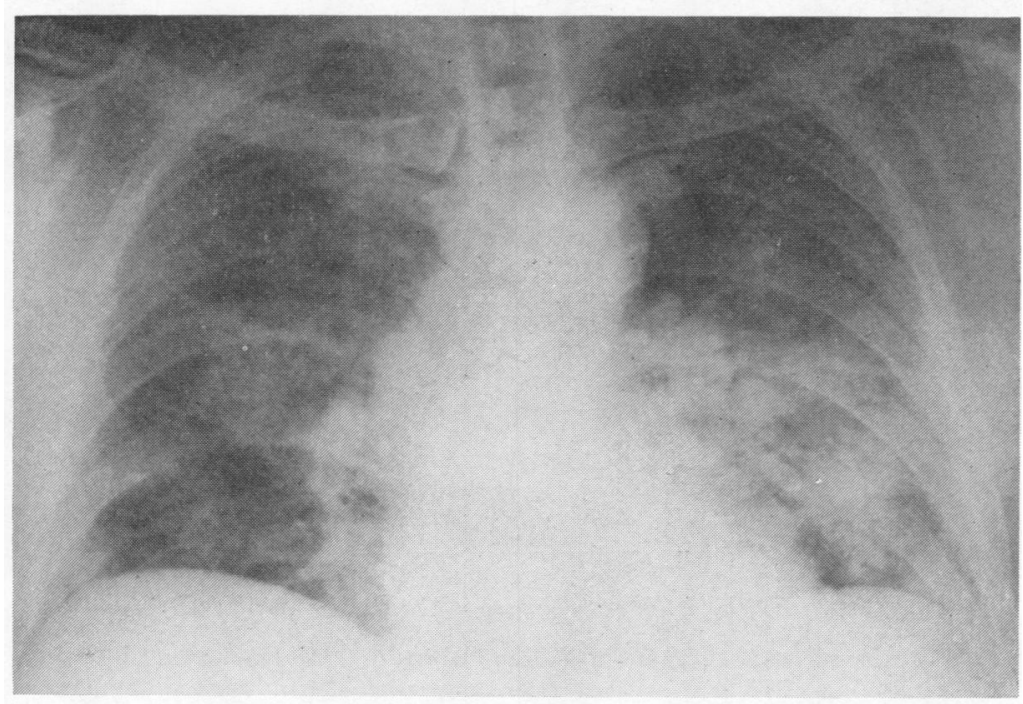

(b)

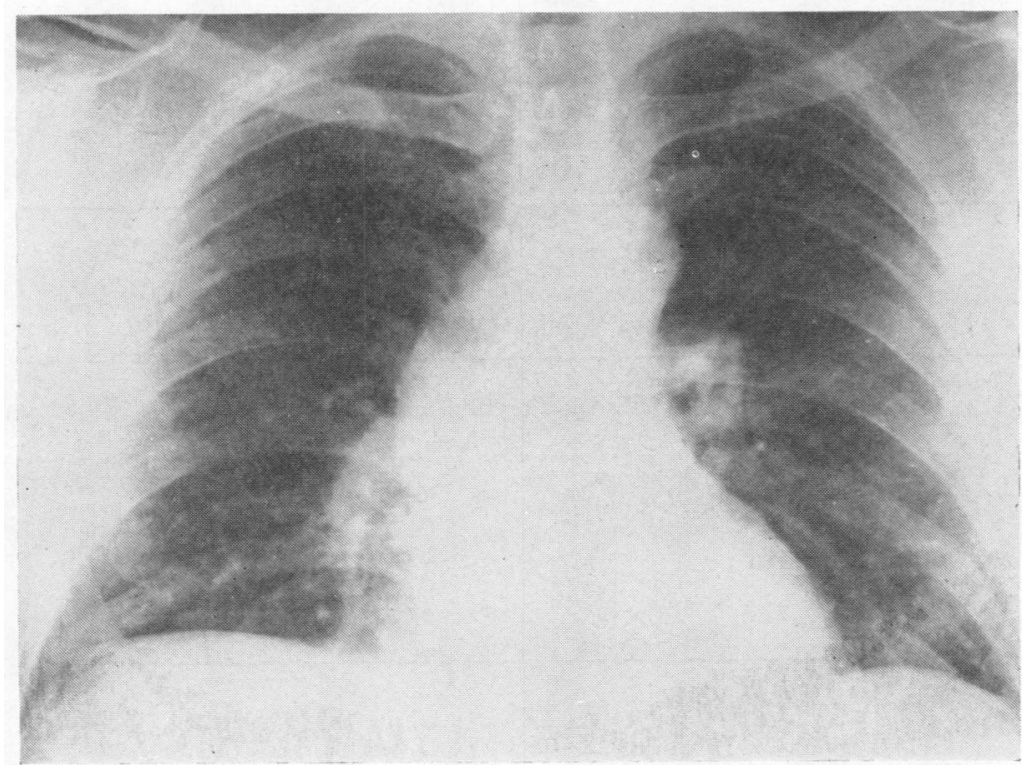

FIGURE Chest radiographs on first patient: (a) pulmonary oedema on day $1 ;(b)$ consolidation on day 7; and (c) normal radiograph two months later.

\section{(c)}


TABLE 3

BLOOD GAS RESULTS

\begin{tabular}{|c|c|c|c|c|c|c|c|c|c|c|}
\hline \multirow{2}{*}{$\begin{array}{c}\text { Case and } \\
\text { day of } \\
\text { study }\end{array}$} & \multirow[b]{2}{*}{ Hours } & \multirow{2}{*}{$\begin{array}{c}\text { Inspired } \\
\text { oxygen } \\
(l . / \text { min. })\end{array}$} & \multicolumn{4}{|c|}{ Arterial blood } & \multirow{2}{*}{$\begin{array}{c}\mathrm{PiO}_{2} \\
(\mathrm{~mm} . \mathrm{Hg})\end{array}$} & \multirow{2}{*}{$\begin{array}{c}\mathrm{PaO}_{2} \\
(\mathrm{~mm} . \mathrm{Hg})\end{array}$} & \multirow{2}{*}{$\begin{array}{c}\text { Observed } \\
A-a D O_{2} \\
(\mathrm{~mm} . \mathrm{Hg})\end{array}$} & \multirow{2}{*}{$\begin{array}{c}\text { Predicted } \\
\mathrm{A}-\mathrm{aDO} \mathrm{O}_{2} \\
(\mathrm{~mm} . \mathrm{Hg})\end{array}$} \\
\hline & & & $\begin{array}{c}\mathrm{PaO}_{2} \\
(\mathrm{~mm} . \mathrm{Hg})\end{array}$ & $\begin{array}{c}\mathrm{PaCO}_{2} \\
(\mathrm{~mm} . \mathrm{Hg})\end{array}$ & $\mathrm{p} H$ & $\begin{array}{c}\text { Base } \\
(m E q / l .)\end{array}$ & & & & \\
\hline $\begin{array}{r}1 \text { Day } 1 \\
2 \\
\\
5 \\
6 \\
7\end{array}$ & $\begin{array}{l}0 \\
3 \\
0 \\
6\end{array}$ & $\begin{array}{c}\text { Air } \\
7 \\
7 \\
7 \\
7 \\
7 \\
7\end{array}$ & $\begin{array}{r}45 \\
70 \\
65 \\
70 \\
154 \\
77 \\
145\end{array}$ & $\begin{array}{l}24 \\
27 \\
21 \\
34 \\
30 \\
26\end{array}$ & $\begin{array}{l}7 \cdot 38 \\
7 \cdot 38 \\
7 \cdot 39 \\
7 \cdot 37 \\
7 \cdot 46 \\
7 \cdot 48 \\
7 \cdot 45\end{array}$ & $\begin{array}{l}-10 \\
-8 \\
-11 \\
-4 \\
-2 \\
-4\end{array}$ & & & & \\
\hline 2 Day 1 & $\begin{array}{l}0 \\
3\end{array}$ & $\underset{7}{\text { Air }}$ & $\begin{array}{r}54 \\
110\end{array}$ & $\begin{array}{l}22 \\
29\end{array}$ & $\begin{array}{l}7 \cdot 39 \\
7 \cdot 39\end{array}$ & $\begin{array}{l}-11 \\
-6\end{array}$ & & & & \\
\hline $\begin{array}{r}3 \\
\text { Day } 1 \\
2 \\
3\end{array}$ & $\begin{array}{l}0 \\
3 \frac{1}{2}\end{array}$ & $\begin{array}{c}\text { Air } \\
10 \\
10 \\
10\end{array}$ & $\begin{array}{r}65 \\
97 \\
193 \\
210\end{array}$ & $\begin{array}{l}17 \\
36 \\
39 \\
33\end{array}$ & $\begin{array}{l}7 \cdot 49 \\
7 \cdot 42 \\
7 \cdot 38 \\
7 \cdot 42\end{array}$ & $\begin{array}{r}-11 \\
0 \\
-\quad 1 \\
-2\end{array}$ & $\begin{array}{l}152 \\
375\end{array}$ & $\begin{array}{l}132 \\
330\end{array}$ & $\begin{array}{r}67 \\
233\end{array}$ & $\begin{array}{r}9 \\
71\end{array}$ \\
\hline 4 Day 1 & & 10 & & 48 & $7 \cdot 37$ & 4 & & & & \\
\hline $\begin{array}{r}5 \\
\text { Day } 1 \\
2 \\
3 \\
4 \\
5 \\
6\end{array}$ & $\begin{array}{l}0 \\
3\end{array}$ & $\begin{array}{c}\text { Air } \\
6 \\
4 \\
4 \\
4 \\
4 \\
\text { Air }\end{array}$ & $\begin{array}{r}55 \\
160 \\
190 \\
217 \\
145 \\
145 \\
111\end{array}$ & $\begin{array}{l}36 \\
33 \\
25 \\
33 \\
36 \\
30 \\
27\end{array}$ & $\begin{array}{l}7 \cdot 29 \\
7 \cdot 39 \\
7 \cdot 41 \\
7 \cdot 45 \\
7 \cdot 40 \\
7 \cdot 41 \\
7 \cdot 42\end{array}$ & $\begin{array}{l}-8 \\
-4 \\
-8 \\
0 \\
-2 \\
-5 \\
-6\end{array}$ & $\begin{array}{l}210 \\
240 \\
148\end{array}$ & $\begin{array}{l}167 \\
203 \\
116\end{array}$ & $\begin{array}{r}22 \\
58 \\
5\end{array}$ & $\begin{array}{l} \\
35 \\
45 \\
11\end{array}$ \\
\hline $\begin{array}{r}6 \\
\text { Day } 1 \\
\\
2 \\
3 \\
5 \\
7\end{array}$ & $\begin{array}{l}0 \\
5\end{array}$ & $\begin{array}{c}\text { Air } \\
6 \\
6 \\
6 \\
6 \\
4\end{array}$ & $\begin{array}{r}84 \\
60 \\
145 \\
130 \\
171 \\
150\end{array}$ & $\begin{array}{l}17 \\
15 \\
32 \\
28 \\
29 \\
26\end{array}$ & $\begin{array}{l}7 \cdot 37 \\
7 \cdot 37 \\
7 \cdot 41 \\
7 \cdot 40 \\
7 \cdot 43 \\
7 \cdot 40\end{array}$ & $\begin{array}{l}-15 \\
-18 \\
-\quad 3 \\
-6 \\
-4 \\
-7\end{array}$ & $\begin{array}{l}152 \\
218 \\
254\end{array}$ & $\begin{array}{l}183 \\
222\end{array}$ & $\begin{array}{r}57 \\
53 \\
52\end{array}$ & $\begin{array}{l}11 \\
14 \\
35\end{array}$ \\
\hline $\begin{array}{r}7 \text { Day } 1 \\
2 \\
3\end{array}$ & & $\begin{array}{l}6 \\
6 \\
8\end{array}$ & $\begin{array}{r}143 \\
54 \\
140\end{array}$ & $\begin{array}{l}35 \\
32 \\
28\end{array}$ & $\begin{array}{l}7 \cdot 44 \\
7 \cdot 43 \\
7 \cdot 47\end{array}$ & $\begin{array}{r}1 \\
-2 \\
-3\end{array}$ & $\begin{array}{l}270 \\
163 \\
217\end{array}$ & $\begin{array}{l}227 \\
126 \\
182\end{array}$ & $\begin{array}{l}34 \\
72 \\
42\end{array}$ & $\begin{array}{l}16 \\
20 \\
39\end{array}$ \\
\hline
\end{tabular}

TABLE 4

Pulmonary Function Results after 8 Weeks' Convalescence

\begin{tabular}{|c|c|c|c|c|c|}
\hline Patient & F.V.C. (l.) & $F . E . V_{\cdot 1}(l)$. & $\begin{array}{c}\text { Residual volume } \\
(\text { l. })\end{array}$ & F.E. $V_{\cdot 1}$ as $\%$ F.V.C. & $\begin{array}{l}\text { Transfer factor } \\
(D L c o)\end{array}$ \\
\hline $\begin{array}{l}1 \\
2 \\
3 \\
4 \\
6 \\
7\end{array}$ & $\begin{array}{lr}2 \cdot 1 & (50) \\
4 \cdot 8 & (100) \\
4 \cdot 5 & (96) \\
2 \cdot 75 & (70) \\
2 \cdot 95 & (61) \\
4 \cdot 65 & (91)\end{array}$ & $\begin{array}{ll}1 \cdot 86 & (60) \\
3 \cdot 6 & (95) \\
3 \cdot 7 & (100) \\
1.45 & (48) \\
2 \cdot 0 & (57) \\
3 \cdot 2 & (94)\end{array}$ & $\begin{array}{l}1.75 \quad(97) \\
1.95(108) \\
2.0 \quad(105) \\
3.55(176) \\
1.9 \quad(95) \\
2.1 \quad(95)\end{array}$ & $\begin{array}{lr}71 & (95) \\
71 & (90) \\
79 & (101) \\
55 & (75) \\
68 & (91) \\
67 & (90)\end{array}$ & $\begin{array}{l}23 \cdot 1 \quad(81) \\
35.4(111) \\
31.8(101) \\
30 \cdot 7(104) \\
27.6 \quad(92) \\
30.0 \quad(98)\end{array}$ \\
\hline
\end{tabular}

Figures in parentheses are percent of predicted normal (Cotes, 1965). 
(Ogilvie, Forster, Blakemore, and Morton, 1957), normal range $18-33 \mathrm{ml} . / \mathrm{mm} . \mathrm{Hg} / \mathrm{min}$.

Blood gases The blood gas results are shown in Table 3. The arterial $p \mathrm{H}$ was normal in three men, high in three, and low in one. Six patients had a low $\mathrm{PaCO}_{2}$ and one had hypercapnia. This patient (no. 4) had chronic obstructive airways disease, and the sample was taken when he was breathing oxygen at $10 \mathrm{l} . / \mathrm{min}$. The plasma base was normal in two men and low in five; four had a base deficit greater than $10 \mathrm{mEq} / \mathrm{l}$. There was significant hypoxaemia $\left(\mathrm{PaO}_{2}\right.$ of $88 \mathrm{~mm}$. $\mathrm{Hg}$ or less) in four out of five patients breathing room air. Three of these four patients had a $\mathrm{PaO}_{2}$ of less than $60 \mathrm{~mm}$. $\mathrm{Hg}$ and therefore by definition these had respiratory failure (Campbell, 1965). In patients 1 and 7 the $\mathrm{PaO}_{2}$ values were low on days 6 and 2 respectively, when compared with the values on the preceding and following days. No reason was found to account for this change. The hypoxaemia was corrected by giving oxygen, except in the first patient, whose $\mathrm{PaO}_{2}$ remained below $70 \mathrm{~mm}$. $\mathrm{Hg}$ for two days. In five patients the $\mathrm{A}-\mathrm{aDO}_{2}$ was two to five times greater than the normal value on eight determinations, and normal in four. This means that the ventilation-perfusion ratio was usually abnormal.

\section{Treatment}

The patients were given oxygen on arrival at the medical centre of the factory and this was continued during their transfer to our unit. We gave oxygen by means of an M-C mask (Catterall, 1960) at flow rates of 4-10 1./min. Because the patients were dyspnoeic and unable to eat a normal diet they were given a liquid diet of milk powder and sugar (Jones and Peaston, 1966). Antibiotics were given to two patients.

\section{Lung function on recovery}

Spirometry, lung volumes, and transfer factor were measured on six patients eight weeks after discharge from hospital (Table 4). The results on five men were normal. Patient no. 4 showed an obstructive pattern with increased residual volume but a normal transfer factor.

\section{Discussion}

The respiratory effects of chlorine have been recognized since it was used as a poison gas in the First World War. Gassing has since occurred at the place of manufacture (Jones, 1952) or during transport (Chasis, Zapp, Bannon, Whittenberger, Helm, Doheny, and MacLeod, 1947; Joyner and Durel, 1962).

The respiratory effects were well described by Drinker (1945): 'The gas affects the mucosa from the top of the respiratory tract to the alveoli. This means increased formation of mucus, turgescence of the mucosa, perhaps direct stimulation of the smooth muscle of the bronchioles with resulting contraction. All this results in blockage of air passages and anoxia of alveolar capillaries; but here again the one most prominent effect is increased delivery of proteinized fluid, which adds to the exclusion of air and the cycle of disaster.'
The chief physiological disturbance is hypoxaemia, which was recognized by Haldane and Priestley (1935) and confirmed by Chasis and his colleagues (1947). Our own results show that in severe poisoning hypoxaemia may not be corrected by giving oxygen at atmospheric pressure. The measurements of the alveolar-arterial oxygen gradient suggest that this investigation is a valuable guide to the severity of the poisoning. In most of our patients the $\mathrm{PaCO}_{2}$ was low, and hence alveolar ventilation was increased.

Oxygen therapy is the most important treatment. This may be given either from a face mask which delivers about $60 \%$ oxygen, or by breathing oxygen under a small positive pressure (Barach, 1944), or by means of intermittent positive pressure breathing from a powered respirator (Flake, 1964). If a patient has chronic obstructive airways disease then the oxygen therapy should be controlled by measurements of $\mathrm{PaCO}_{2}$.

Antibiotics should be given if the sputum is purulent. We gave our first patient prednisolone, anticipating that it would suppress the inflammatory lung reaction, but we have no proof that this happened. Since chlorine gassing may cause bronchospasm with wheeze and reversible airways obstruction, bronchodilator drugs were used by Barach (1944) and Flake (1964) but were not given to our patients.

Our investigation was supported by a grant from the Research Committee of the United Liverpool Hospitals. We are indebted to Dr. C. M. Ogilvie for the lung function tests. Dr. R. E. Flake kindly provided references to the literature.

\section{References}

Barach, A. L. (1944). The treatment of pulmonary edema due to gas poisoning in war and in civilian life, with special reference to the use of positive-pressure respiration. New Engl. J. Med., 230, 216-223.

Campbell, E. J. M. (1965). Respiratory failure. Brit. med. J., 1, 14511460.

Catterall, M. (1960). A new mask for delivering oxygen or other gases. Ibid., 1, 1941-1942.

Chasis, H., Zapp, J. A., Bannon, J. H., Whittenberger, J. L., Helm, J., Doheny, J. J., and MacLeod, C. M. (1947). Chlorine accident in Brooklyn. Occup. Med., 4, 152-176.

Cotes, J. E. (1965). Lung Function. Pp. 338-356, Blackwell Scientific Publications, Oxford.

Drinker, C. K. (1945). Pulmonary Edema and Inflammation. Harvard Univ. Monographs in Medicine and Public Health, No. 7, p. 52 Harvard University Press, Cambridge, Mass.

Douglas, C. G., and Priestley, J. G. (1948). Human Physiology. 3rd ed., p. 1. Oxford University Press, London.

Flake, R. E. (1964). Chlorine inhalation. New Engl. J. Med., 271, 1373.

Flenley, D. C., Millar, J. S., and Rees, H. A. (1967). Accuracy of oxygen and carbon dioxide electrodes. Brit. med. J., 2, 349-352.

Haldane, J. S., and Priestley, J. G. (1935). In Respiration, 2nd ed. p. 224. Oxford University Press, London.

Jones, A. T. (1952). Noxious gases and fumes. Proc. roy. Soc. Med., 45, 609-610.

Jones, E. S., and Peaston, M. J. T. (1966). Metabolic care during acute illnesses. Practitioner, 196, 271-275.

Joyner, R. E., and Durel. E. G. (1962). Accidental liquid chlorine spil in a rural community. J. occup. Med., 4, 152-154. 
Medical Research Council. (1965). Definition and classification of chronic bronchitis for clinical and epidemiological purposes. Lancet, 1, 775-779.

Ogilvie, C. M., Forster, R. E., Blakemore, W. S., and Morton, J. W. (1957). A standardized breath holding technique for the clinical measurement of the diffusing capacity of the lung for carbon monoxide. J. clin. Invest., 36, 1-17.

Raine, J. M., and Bishop, J. M. (1963). A-a difference in $\mathrm{O}_{2}$ tension and physiological dead space in normal man. J. appl. Physiol., 18, 284-288.

Schatzki, R., cited by Shanks, S. C., and Kerley, P. (1962). A Textbook of X-ray Diagnosis. 3rd ed., Vol. 2, p. 634. Lewis, London.
Semple, S. J. G., Mattock, G., and Uncles, R. (1962). A buffer standard for blood $p \mathrm{H}$ measurements. J. biol. Chem., 237. 963-967. Severinghaus, J. W., and Bradley, A. F. (1958). Electrodes for blood $\mathrm{PO}_{2}$ and $\mathrm{PCO}_{2}$ determination. J. appl. Physiol., 13, 515-520.

Siggaard Andersen, O. (1963). Blood acid-base alignment nomogram. Scand. J. clin. Lab. Invest., 15, 211-217.

, Engel, K., Jørgensen, K., and Astrup, P. (1960). A micro method for determination of $p \mathrm{H}$, carbon dioxide tension, base excess and standard bicarbonate in capillary blood. Ibid., 12, 172-176.

Received for publication October 22, 1968 